\title{
Mata Kuliah Musik Pop dalam Kurikulum Pendidikan Tinggi Seni di Indonesia
}

\author{
M. Hari Sasongko \\ Sekolah Tinggi Theologia, Ungaran, Jawa Tengah, \\ telp.+62 87880021173; e-mail: harisa23@yahoo.co.id
}

\begin{abstract}
Pop music is a musical genre that so close with the television program. Through television, this music has been unseparated from the mass. This music is also by design as the mass culture because it massively produced for people. Pop music is an entertainment music. Through the entertainment, people could gain pleasure. On the other hand, this music is also produced and oriented merely for profit, because it is created to meet the market needs and its gratification. Because it is created for the interest of common people, then I shouldn't astound us if this music's lyrics are much easier to be memorized. It has a much simpler melody line and chord progressions, and it is also flexible as this music is very adaptable to other kinds of music. Can this pop music which has entertainment as a goal, be used for an education program? If it has to be so, the character of pop music as an educational music can be appropriated with its music character: the more simple the music is, the better chances to be considered according to its marketing aspects. If someone who has an interest in composing songs within this genre, he or she should develop a relationship with television programs because this genre fits better in that setting.
\end{abstract}

Keywords: pop music; mass culture; television; curriculum.

\begin{abstract}
Abstrak
Musik pop adalah suatu genre yang sangat dekat dengan televisi. Melalui televisi, musik ini menjadi tak terpisahkan dengan massa. Musik ini juga merupakan mass culture karena diproduksi secara massal bagi masyarakat yang masif. Musik pop merupakan musik hiburan. Dari hiburan itu orang memperoleh kesenangan. Selain itu, musik ini juga berorientasi pada keuntungan karena diciptakan untuk memenuhi kebutuhan dan kepuasan pasar. Oleh karena diciptakan untuk kepentingan massa, maka tidak mengherankan jika musik ini memiliki syair yang mudah dihafal, alunan melodi dan progresi akord yang sederhana, serta bersifat fleksibel, dalam arti mudah beradaptasi dengan jenis-jenis musik yang lain. Masalahnya adalah dengan karakteristik seperti ini dapatkah musik yang 'main-main', yang tampil dengan tujuan menghibur ini 'diangkat' menjadi materi baku di dalam kurikulum pendidikan tinggi yang tentu saja bersifat serius sesuai dengan karakter ilmu pendidikan? Jika memang harus dilakukan, maka sifat kependidikannya harus disesuaikan dengan karakter musik ini: semakin sederhana, semakin baik. Semakin baik lagi jika mampu membangun relasi dengan acara di televisi.
\end{abstract}

Kata Kunci: Musik pop; budaya massa; televisi; kurikulum.

\section{Pengantar}

Disadari atau tidak, suka atau tidak suka, musik pop mengalami perkembangan yang luar biasa dewasa ini. Perkembangan ini tampaknya tidak linear dengan saudaranya, musik serius (musik seni), yang masih 'berjalan di tempat' dan juga masih terkesan 'klasik'. Akan tetapi dalam konteks pengembangan kurikulum pendidikan musik, kenyataan justru berbicara lain: kalau musik serius sudah mampu menempatkan dirinya sebagai sosok yang 'settled', bahkan 'established', kurikulum musik pop justru masih tertatih-tatih dalam proses pembentukan, bahkan gamang dalam proses perumusan visi-misinya.

Tulisan ini sama sekali tidak dimaksudkan untuk terlibat di dalam kancah 
perdebatan 'klasik versus pop', melainkan memberikan suatu gambaran yang rasional mengenai fenomena musik pop yang, di beberapa perguruan tinggi yang menyelenggarakan pendidikan musik, mulai diperhitungkan sebagai genre penting dan diberi ruang di dalam konteks akademis dalam wujud kurikulum pembelajaran. Selanjutnya di dalam tulisan ini akan dipaparkan hakikat musik pop. Hakikat musik ini sudah seyogianya jika dipertimbangkan sebagai dasar penyusunan kurikulum pembelajaran genre ini.

Dieter Mack pernah mengungkapkan, "istilah 'musik populer' berhubungan dengan media massa, dan mau tidak mauberhubungan dengan unsur kuantitatif dari segi keuntungan uang "(Mack, 1995: 18). Itu berarti musik populer tidak dapat dipisahkan dari populer culture atau mass culture (budaya massa). Oleh karena itu, perihal mass culture akan dipaparkan terlebih dahulu agar pembahasan menjadi lebih komprehensif.

\section{Pembahasan}

\section{Makna dan Karakter Mass culture}

Fenomena mass culture atau populer culture atau budaya massa mulai mendapat perhatian yang serius dari berbagai bidang ilmu. Selain melalui kajian sosial, fenomena ini juga dikaji secara ekonomis, filosofis, dan psikologis, bahkan di beberapa Sekolah Tinggi Teologi (STT) Kristen di Indonesia, fenomena ini mulai dikaji secara teologis. Walaupun kajian atas fenomena ini masih relatif baru, sesungguhnya makna dan istilah ini memiliki latar belakang sejarah yang relatif cukup panjang.

Gans (1974: 9-10) mencatat, awalnya istilah ini merupakan kombinasi dari dua pemikiran (ide) di kalangan intelektual Jerman, yakni masse dan kultur. Masse merujuk pada golongan non-aristokratik; suatu golongan masyarakat di kawasan Eropa yang kurang berpendidikan. Lambat laun makna ini berkembang dan muncullah istilah mass (massa) yang sering dipakai untuk merujuk pada golongan (kelas) menengah ke bawah; miskin; orang kebanyakan (common people). Di dalam konteks budaya Jawa mungkin setara dengan istilah 'wong cilik'. Inilah low culture. Sebaliknya, istilah kultur mengandung pengertian kebalikan (negasi) dari masse, yakni golongan terpelajar, bukan hanya terbatas pada bidang ilmu, tetapi juga cara berpikir, cara berperilaku, cara memandang (berperasaan) terhadap sesuatu. Istilah ini pada akhirnya mengacu pada sekelompok orang yang dianggap 'berbudaya' atau mereka 'yang telah dibudayakan'; mereka adalah golongan priyayi; golongan high culture. Istilah mass culture juga mengacu pada produk-produk yang digunakan oleh sebagian besar kaum yang 'kurang terdidik', yang bersifat massal. Di dalam bahasa Jerman, istilah mass culture dikenal juga dengan sebutan kitsch (MacDonald, 1964: 59).

Secara historis tidak diketahui dengan pasti lahirnya istilah ini. Namun demikian, menurut catatan J. Gans, istilah mass culture lahir di awal abad ke 19 di Eropa (Gans, 1974: 10). Gans menceritakan, pada saat itu di Eropa dunia politik dan kualitas pendidikan di masyarakat merosot tajam, bahkan mengarah kepada dekadensi moral, akibat tindakan golongan kelas atas (para bangsawan) yang memonopoli setiap aspek kehidupan (kebijakan) di masyarakat, termasuk munculnya kebijakan penarikan pajak yang cukup tinggi. Namun demikian, kondisi masyarakat tersebut ternyata berbanding terbalik dengan perkembangan teknologi. Penemuan demi penemuan muncul justru di tengah-tengah siatuasi ekonomi yang chaos itu. Kondisi ini tidak luput dari pantauan perusahaan-perusahaan besar, dan dengan mudah bisa mengeruk keuntungan dari keadaan tersebut dengan memproduksi barang-barang kebutuhan secara massal dengan harga murah. Barangbarang itu bisa berupa kebutuhan rumah 
tangga, lukisan, buku, termasuk musik. Barang-barang tersebut sengaja dibuat secara massal untuk memenuhi permintaan pasar yang masif dan demi kepuasan pasar (Lih. Kotler, 1997: 8). Dari kondisi ini terciptalah masyarakat industri. Dalam masyarakat industri semua barang diproduksi sematamata untuk mencari keuntungan (Gans, 1974: 11-15; Strinati, 2007: 12).

Dalam perkembangan selanjutnya istilah mass culture mulai dihubungkan dengan makna pejoratif. Mass mulai diartikan sebagai massa - kerumunan tanpa identitas atau jatidiri yang jelas. Kehadiran mass bukan diatasnamakan secara personal atau individual; tidak pula mengatas namakan suatu kelompok tertentu. Dari perkembangan makna tersebut, maka mass (massa) dapat diartikan sebagai 'kerumunan orang yang kurang berbudaya' (mob's lack of culture). Dari uraiannya itu Gans lantas menarik simpul bahwa hakikat 'massa' setidaknya memiliki tiga karakteristik, yakni (1) memiliki jumlah yang besar, (2) hubungan antarindividunya tidak terdapat hubungan organisatoris, dan (3) masing-masing individu memiliki latar belakang sosial yang berbeda-beda (Gans, 1974: 15). Di Indonesia dewasa ini istilah 'massa' secara sosial mengalami perkembangan makna baru. Istilah yang semula merupakan kata benda berubah jenis menjadi kata kerja dengan munculnya istilah 'dimassa' yang berarti 'dihajar, dipukuli, dianiaya beramai-ramai'.

Mass culture, sebagai istilah yang dalam perkembangan selanjutnya lebih dihubungkan dengan bidang ekonomi atau perdagangan, terutama yang diproduksi secara massal atau masif. Oleh karenanya bisa berada di mana-mana. Oleh karena ada di mana-mana, maka barang ini mudah ditemui, mudah didapat, mudah pula diimitasi, atau ditiru sehingga barang tersebut menjadi dikenal banyak orang (well known): barang ini menjadi populer karena dikenal di berbagai populasi, maka lahirlah istilah 'budaya populer'. Frase "berbagai populasi" perlu mendapat penekanan sebab istilah 'populer' ini kenyataannya memang digunakan secara berbeda, pada saat yang berbeda, tempat, dan konteks yang berbeda, dan oleh orang-orang (komunitas) yang berbeda pula (Merriam-Webster's, 2001: 904). Roy Shuker bahkan lebih menekankan bahwa istilah ini sebenarnya bukan sematamata adjective (kata sifat), tetapi juga noun (kata benda) (Shuker, 1994: 3). Ini mengandung konsekuensi bahwa pengertian atau makna 'popular' menjadi semakin luas.

Jadi, budaya massa adalah budaya popular yang dihasilkan melalui teknikteknik industrial (yang menghasilkan produk-produk massal untuk masyarakat yang masif) yang dipasarkan, didesiminasi, untuk mendapatkan keuntungan yang sebesar-besarnya bagi pemilik modal (kapitalis). Oleh karena orientasinya adalah keuntungan, maka pertumbuhan budaya ini berarti mempersempit ruang bagi budaya yang tidak menghasilkan uang.

Dalam konteks musik, produkproduk ini dapat berupa musik seni ataupun tradisional. Kedua jenis musik ini umumnya bersandar pada penciptaan yang rumit, menitikberatkan kompleksitas kreativitas, intelektualitas, pemahaman filosofi dan entitas budaya. Karakter seperti ini tentu saja jauh dari urusan komersial, kecuali memang sengaja 'di-low culture-kan'. Karakter ini diperkuat oleh ciri lain, yakni dalam konteks budaya massa, selera estetis kerumunan diseragamkan. Kecenderungan penyeragaman selera estetis itu disebut aesthetics trend. Inilah yang banyak dikritik oleh para posmodernis, sebab jika terjadi penurunan standar estetis, maka penurunan itu bersifat serentak (Collins, 1989: 113).

\section{Televisi dan Budaya Massa}

Televisi dan budaya massa adalah dua hal yang tidak bisa dipisahkan. Keduanya berkorelasi sedemikian rupa, sehingga saling mendukung, saling menghidupi, dan saling berkolaborasi. 
Sebelum memasuki pembahasan mengenai hubungan antara budaya massa dengan televisi, maka perlu dijelaskan yang dimaksud dengan 'televisi' (walau hanya sangat sekilas) berikut karakternya.

Televisi pertama kali dioperasionalkan pada tahun 1926 oleh seorang Skotlandia, John Logie Baird, yang merupakan kombinasi teknologis antara film dengan radio. Televisi dengan mutu yang jauh lebih baik diperlihatkan kepada publik tahun 1939 lewat suatu pameran televisi di New York World's Fair (Daniels, 2003: 293). Televisi adalah 'teknologi' sekaligus 'medium'. Makna teknologi bagi medium sama halnya makna otak bagi pikiran. Seperti halnya otak, sebuah teknologi merupakan perkakas fisik, sedangkan sebuah medium, seperti halnya alam pikiran, merupakan suatu kegunaan tempat perkakas tersebut dipakai. Teknologi menjadi medium ketika sejumlah kode simbolis tertentu digunakan, ketika ditempatkan di suatu latar sosial tertentu, dan ketika diselipkan ke dalam konteks sosial dan politis tertentu (Ginsburg, 2002: xvii). Dengan kata lain, teknologi pada dasarnya merupakan mesin semata, sedangkan medium merupakan lingkungan sosial dan intelektual yang diciptakan sebuah mesin.

Frith mengungkapkan, televisi pada hakikatnya adalah mesin komersial milik para kapitalis. Semakin sinis Frith menyatakan, televisi adalah kepanjangan tangan dari para kapitalis untuk mengeruk keuntungan tanpa batas, dan generasi dunia saat ini tidak lain adalah generasi yang diperbudak oleh mesin komersial itu (Frits, 1983: 109). Akan tetapi di sisi lain, Raymond William menyikapi kehadiran 'kotak ajaib' itu secara lebih halus, bahwa tak dapat dipungkiri televisi memang memiliki kekuatan uyntuk mengubah sesuatu; "television, like any other tecnology, become available as an element or a medium in process of change," (William, 2000: 9). Televisi, dengan demikian, juga merupakan agen perubahan.
Kekuatan televisi terletak pada ikonoklasme, yakni kemampuan menciptakan citra-citra baru (new image) dan menghapus citra-citra lama (old image). Televisi mendobrak, mengubah, dan menggantikan image pemirsanya tentang sesuatu: kreativitas (seni), tokoh, gaya hidup, produk, jasa, bahkan mungkin saja keyakinan (iman) seseorang terhadap sesuatu. Menurut Labib, Bintang film, penyanyi, wartawan televisi, pembaca berita adalah agen-agen ikonoklasme yang kuat. Namun yang ikon yang paling bertanggung jawab adalah iklan. Iklan bukan lagi sekadar icon, melainkan super-icon (Labib, 2002: 18).

Iklan di televisi sangat dipengaruhi, bahkan tergantung dari audience rating (tingkat ketertontonan acara televisi). Melalui audience rating dapat diketahui tingkat popularitas sebuah acara siaran televisi di mata pemirsanya, yang biasa disebut 'pasar pemirsa'. Tingkat audience rating sangat tergantung dari 'acara', dan sejauh mana acara diterima oleh pemirsa sangat tergantung orang-orang di balik acara itu, yang disebut sebagai ikonoklasme tadi. Inilah satu karakter yang menunjukkan bahwa urusan televisi pada hakikatnya adalah urusan perputaran uang.

Di televisi, semua itu sangat memungkinkan, sebab seperti yang diungkap Tschmuck, "technological possibilities expand, new music practice emerge, the number of actors increase, and new business from during the period of paradigm change," (Tschmuck, 2006: 209).

Karakter lain yang tidak kalah penting karakter televisi yang bersifat 'menghibur' sehingga menciptakan per-mainan. Hubungan ini bersifat korelatif sebab permainan juga menciptakan hiburan. Lewat bermain, manusia men-dapatkan kenikmatan, kepuasan, kesegaran kembali, dan perasaan lega. Manusia menyukai hiburan dan permainan karena hal itu memang menyenangkan dirinya. Pada tahun 1938, sejarawan Belanda Johan Huizinga (1872- 
1945) memperkenalkan sebuatan baru bagi manusia, yakni homo ludens (makhluk bermain); "bermain merupakan unsur konstitutif dalam eksistensi manusia dan mencirikan siapa manusia itu sebenarnya," (Hariyadi, 1995: 338-342). Dalam suatu hiburan, permainan menemukan bentuknya yang konkret.

Itulah televisi sebagai media massa; media untuk massa; media 'milik' massa. Sebagai media, televisi tidak hanya memiliki fungsi komunikatif, tetapi juga memiliki fungsi lain yang tersembunyi yang disadari atau tidak telah serba menentukan pemikiran, persepsi, opini, bahkan perilaku orang. Televisi adalah penyampai imaji. Imaji tidak terbatas pada sesuatu konkretvisual (kasat mata), melainkan juga sesuatu yang 'tampak' dan hadir di dalam batin. Inilah yang disebut 'the hidden existence' oleh Horowitz dalam "Theory of Imagination"-nya (Neuman, 1978, No.3).

Ini berarti pula bahwa pesan-pesan yang disampaikan oleh televisi tidak pernah bermakna tunggal. Pesan-pesan itu harus ditafsirkan. Itu pula yang menjadi sebab turunnya credo Marshall McLuhann, "medium is a message": media tidak lagi (hanya) menyampaikan pesan karena media itu sendiri adalah pesan. Dengan kata lain, medium itu sendiri merupakan pesan sebab 'segala sesuatu yang dikatakan' ditentukan secara mendalam oleh medianya.

Selanjutnya, hubungan televisi dengan budaya massa sangat rumit, namun unik. Di dalam konteks televisi, budaya massa harus dibedakan menjadi dua, yakni (1) budaya massa dalam hal barang dagangan yang diproduksi oleh para kapitalis, yang dipublikasikan dalam bentuk iklan di televisi dan (2) budaya massa dalam arti 'acara', yang dibuat oleh para ikonoklasme, yang kemasannya bisa berupa talkshow, pergelaran musik, film, sinetron, news, infotainment, acara intermeso: kuliner, kecantikan, hobi, dan sebagainya. Di dalam televisi kedua budaya massa ini berjalan secara bersamaan dan sinergis, tidak terpisah-pisah, tidak berdiri sendiri-sendiri, melainkan merupakan satu kesatuan. Yang prinsip adalah baik produsen barang-barang dagangan, pemilik televisi, dan para artis (ikonoklasme) mempunyai tujuan yang sama, yakni memperoleh keuntungan yang sebesar-besarnya yang didapat dari massa, dalam hal ini disebut 'pemirsa', sedangkan pemirsa sendiri mendapatkan kesenangan dari hubungan yang korelatif itu. Ini sesuai dengan konsepsi Ben Agger bahwa pada hakikatnya mass culture memang tidak dibangun berdasarkan konsep yang hakiki dan substansial, melainkan di atas dasar kesenangan, namun tidak substansial dan semata-mata untuk mengentaskan orang dari kejenuhan kerja sepanjang hari (Agger, 1992: 24).

Hubungan televisi dengan pemirsanya bersifat langsung, namun hubungan produsen barang-barang dan ikonoklasme bersifat tidak langsung. Dalam hubungan itu tampak televisi berperan dan berfungsi sebagai 'mediator' yang sangat strategis; perantara antara produsen barang dagangan dengan massa di satu sisi; perantara antara ikonoklasme dengan massa (pemirsa) di sisi lain.

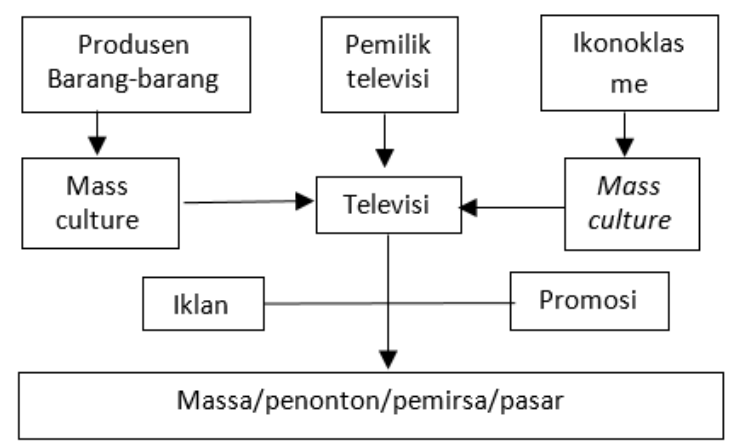

Ilustrasi 1.

Diagram alur pengaruh TV pada audiens

Yang menjadi masalah adalah si perantara itu justru merupakan pihak yang ikut 'bermain' di dalam kancah hubungan 
ini; dialah si pemilik modal di balik stasiun televisi; si perantara masuk ke dalam arena permainan bisnis dan menjadi pihak yang paling menentukan dalam hal apapun sebelum materi acara masuk ke dalam televisi, termasuk urusan selera atau estetika jika dikaitkan dengan urusan musik.

Dari diagram di atas (ilustrasi 1) jelas, bahwa pengaruh televisi sangat kuat. Lewat televisi, mass culture bukan hanya sampai kepada massa, tetapi lebih dari itu semakin dihayati sebagai kebutuhan yang harus dipenuhi karena hadir secara terusmenerus. Yang justru menjadi masalah adalah massa tidak memiliki counter culture dan semata-mata menerima; massa, dalam hal ini menjadi pihak yang pasif, menjadi objek ketimbang subjek. Kondisi yang berlangsung terus-menerus seperti ini akan mengakibatkan munculanya pola ketergantungan yang mendalam terhadap produkproduk yang ditawarkan. Jika sudah seperti ini, maka televisi sebetulnya bukan sematamata 'alat', tetapi lebih dari itu 'senjata' (dalam konteks ini) bagi para produsen barangbarang, artis, stake-holder, untuk mendapatkan keuntungan yang sebesarbesarnya dengan selalu membangun mitos bahwa produksinya merupakan kebutuhan dasar yang bisa tidak bisa harus dipenuhi.

\section{Musik Pop dan Televisi}

Istilah 'musik pop' sebetulnya masih bersifat ambigu. Musik ini sering begitu saja disebut sebagai 'musik modern' sekadar untuk membedakannya dengan 'musik klasik'. Di kalangan sekolah tinggi teologi istilah 'musik pop' sering disebut dengan 'musik kontemporer' sekadar untuk menyatakannya sebagai ' musik masa kini'. Apapun istilahnya, yang jelas musik ini sangat sering hadir di televisi dan merupakan salah satu bentuk kebudayaan modern di dalam masyarakat modern. Kenyataan itu menjadi indikator bahwa musik pop memiliki hubungan yang dekat, bahkan tidak terpisahkan dari televisi sebagai wujud budaya modern pula. Agar dapat memperoleh hubungan yang jelas antara televisi dengan musik pop, maka berikut ini akan dijelaskan hakikat musik pop. Penjelasan mengenai musik pop ini sangat penting karena tampaknya beberapa karakter di dalam musik pop satu paradigma dengan mass culture, bahkan dengan karakter televisi itu sendiri.

Seperti telah disinggung di awal tulisan ini, istilah 'pop' berasal dari kata 'populer'. Suka Hardjana secara langsung mengatakan, musik pop adalah "musik orang kebanyakan (common people), komersial, dan merupakan salah satu bentuk dari pengaruh kebudayaan Barat," (Hardjana, 2002). Oleh karena merupakan musik orang kebanyakan, maka musik pop sesungguhnya memiliki karakter yang spesifik pula yang tidak jauh dari karakter mass culture. Salah satu karakternya adalah adanya 'kemudahan' yang meliputi eksistensi musik ini. Karakter lain yang cukup penting adalah bersifat 'menghibur'. Dengan kata lain, oleh karena ditujukan untuk menghibur, maka segalanya dibuat mudah. Tidak pernah ada hiburan yang prosesnya jlimet; rumit; berbelit-belit. Sebuah hiburan diciptakan agar orang bisa menikmati permainan yang terkandung di dalam hiburan itu, agar orang merasa senang tanpa harus melibatkan aktivitas pikiran yang sungguh-sungguh. 'Kemudah-an' di dalam musik pop bisa meliputi (1) syair yang mudah dihafal dan tidak melibatkan pemikiran filsafat yang complicated serta bersifat langsung, (2) alunan melodi yang bersifat melodius, (3) harmoninya tidak terlalu rumit, misalnya cenderung menggunakan progresi akord yang sederhana, (4) menghentak keras, sehingga menggunakan alat musik band, yang tentu melibatkan penggunaan listrik, (5) bersifat fleksibel, artinya sebuah lagu bisa dengan mudah menyesuaikan diri dengan style apapun, (5) memiliki tempo yang (relatif) lebih bervariasi. 
Pandangan semacam ini ternyata tidak selalu benar, sekurang-kurangnya menurut pandangan Adorno, lewat tulisan Andy Hamilton. Beberapa lagu klasik seperti karya Mozart dan Vivaldi bisa menjadi nge-pop, walaupun karya mereka bukan produk dari industri budaya. Karya mereka hanya masuk ke dalam kriteria 'populer' (Adorno menyebutnya sebagai 'popular classic'), namun tidak di dalam karakter musik pop itu sendiri dalam arti genre. $\mathrm{Na}-$ mun demikian, kasus ini hanya sebagian kecil dari karya-karya klasik yang pernah ada. Hamilton menulisnya sebagai berikut.

The culture industry is often assumed to embrace only popular music and arts, but this is a misinterpretation of dorno's concept. It is also includes art music of the past that has been transformed into 'museum-art', as well as 'moderate', nonmodernist music of the present time that makes compromises in order to be accessible. For instance, Mozart's Symphony No.40 and Vivaldi's 'The Four Seasons' have become popular clasic and, hence, commodified -Adorno would have marvelled at, and been appaled by, their appropriation by the mobile ring tone industry. But unlike commodified pop music, the work of Vivaldi and Mozart was not originally a produck of the culture industry (Hamilton, 2007: 172).

Akan tetapi Adorno dan Horkheimer, lewat analisis Janet Wolff, samasama menyetujui adanya makna industri budaya di dalam jazz, walaupun secara umum dapat dikatakan, karakter jazz dari nsisi teknik permainan berbeda dengan pop. Janet Wolff menulis,

"Jazz, like other products of what Adorno and Horkheimer called 'the culture industry' demans 'psychological regression' and denies individuality and individual needs, while pretending to acknowledge and gratify them," (Wolff, 1993: 89).
Sifat lain yang juga melekat di dalam karakter musik pop adalah musik ini 'berumur pendek', tidak bertahan lama, atau mudah 'usang'. Di dalam blantika musik pop, tidak mengherankan jika selama hidupnya seorang pencipta lagu bisa menciptakan puluhan, bahkan ratusan lagu dalam satu tahun. Sebabnya adalah, pertama, karena mudah diciptakan, kedua, pasar selalu menuntut sesuatu yang baru secara cepat. Jika dihubungkan dengan pendapat Arnold Hauser, kenyataan ini tampaknya menjadi mudah dipahami. Oleh karena musik pop merupakan budaya modern, maka karakternya membawa sifat bawaan dari masyarakatnya, yakni kebosanan (boredom) dan kegelisahan (reslessness). Menurut Arnold Hauser, kedua hal inilah yang mendasari lahirnya seni populer (Hauser, 1982: 580).

Maka jelaslah, bahwa karakter yang dimiliki musik pop (sebagai salah satu bentuk mass culture) sama dan sebangun dengan televisi. Satu 'benang merah' yang dapat ditarik dari ketiga hal itu adalah adanya kepentingan ekonomi, yakni mencari keuntungan sebesar-besarnya (selain tentu saja ada kepentingan lain yang bersifat sekunder). Kontemplasi dan paradigma filosofis yang biasanya menyertai proses penciptaan musik seni atau musik serius, tidak diperlukan lagi di sini. Teknik yang tinggi dalam memainkan instrumen, interpretasi lagu bukan lagi menjadi hal yang terlalu penting, walaupun kadang-kadang tetap saja menjadi hal menentukan untuk lagu-lagu yang memiliki kualitas lebih tinggi.

Selera individu yang seharusnya berangkat dari 'living form' (meminjam istilah filsuf Amerika Sussane K. Langer), tidak lagi bersifat substansial ketika musik pop berada di televisi (Sasongko, 2002). Pendeknya, ketika musik pop berada di televisi, ia tidak lepas dari urusan hiburan, kesenangan, dan dagang. 
Kenyataan seperti ini bagaimana pun membawa konsekuensi logis pada nilai estetisnya. Oleh karena memiliki paradigma hiburan, kesenangan, dan dagang, maka standar estetisnya juga berorientasi ke ketiga hal tersebut, yakni dikembalikan kepada massa atau pasar. Pasarlah yang menentukan ukuran baik tidaknya sebuah lagu; artis manakah yang pantas diorbitkan. Penilaian estetis ini pada dasarnya bukan berasal dari ahli musik atau musikolog.

Dalam konteks pertelevisian, keindahan di dalam musik pop sungguhsungguh ditentukan oleh pemirsanya. Pemenang Grammy Awards sebagai misal, dipandang sangat berprestasi di dalam bidang musik pop, pertama-tama jika dilihat dan dinilai dari berapa copy rekamannya terjual dalam waktu pendek tertentu. Berbagai acara televisi di Indonesia berupa ajang kompetisi musik, seperti 'Indonesian Idol' (RCTI) tidak menyerahkan si pemenang kepada ahli musik, tokoh musik, atau musikolog, melainkan tergantung pada berapa banyak SMS yang diterimanya.

Sebagai catatan, Grammy Awards merupakan kependekan dari Gramaphone Awards merupakan acara bergengsi; sebuah penghargaan yang diberikan oleh $\mathrm{Na}-$ tional Academy of Recording Arts and Sciences di Amerika Serikat untuk mengakui prestasi yang luar biasa di bidang industri musik. Di dalam kancah musik pop, untuk menentukan siapa yang terbaik sebetulnya bukan tergantung uraian kritik musik dari pengamat seni, melainkan dari penontonnya. Pendek kata, estetika atau nilai estetis musik pop semata-mata ditentukan oleh pasar, bukan yang lain.

\section{Mata Kuliah Musik Pop pada Pendidi- kan Tinggi di Indonesia}

Dengan karakteristik musik pop seperti diuraikan panjang lebar di atas dan fakta kedekatannya dengan televisi dan mass culture seperti itu, maka muncul pertanyaan yang menggelitik, mungkinkan membuat formulasi mata kuliah genre musik ini di tingkat pendidikan tinggi? Mungkinkah musik ini bisa beradaptasi dengan paradigma humanis yang senantiasa ditekankan di dalam filsafat pendidikan? Mungkin di sinilah letak kesulitannya.

Formasi mata kuliah berorientasi pada visi-misi sebagai suprastruktur. Berdasarkan visi-misi inilah kurikulum dirumuskan. Rumusan kurikulum ini menjadi dasar dalam menurunkan rangkaian mata kuliah. Menurut SK Mendiknas No. 232/U/ 2000, pengertian kurikulum di pendidikan tinggi adalah "seperangkat rencana dan pengaturan mengenai isi maupun bahan kajian dan pelajaran serta cara penyampaian dan penilaiannya yang digunakan sebagai pedoman penyelenggaraan kegiatan belajar mengajar di perguruan tinggi." Kurikulum diperlukan sabagai elemen guna mencapai tujuan pendidikan tinggi yang pada prinsipnya adalah mempersiapkan seseorang dengan kualifikasi kesarjanaan, yang siap menyesuaikan diri dengan perubahan cepat yang mungkin dihadapinya dalam profesi atau lapangan kerja yang digelutinya.

Hakikat dan karakter musik pop yang telah dipaparkan di atas pada akhirnya mempengaruhi rumusan visi-misi. Dengan kata lain, rumusan visi-misi tidak boleh menyimpang dari hakikat dan karakter musik pop. Konsekuensi logisnya, rumusan visi-misi ini menjadi dasar kurikulum, dan hal ini tentu saja mempengaruhi isi maupun bahan kajian dan pembelajaran dari mata kuliah yang diturunkan. Mata kuliah seperti Sejarah Musik sebagai misal, tidak bisa disamakan begitu saja dengan materi mata kuliah Sejarah Musik Barat yang selama ini diajarkan di perguruan tinggi yang menyelenggarakan pendidikan musik serius. Mata kuliah ini sudah seyogianya disebut Sejarah Musik Pop, yang sudah barang tentu memiliki materi yang berbeda. 
Selain itu, penentuan tingkat kesulitan (grade) pada tataran praktik sudah seyogianya mengacu pada filosofi atau konsepsi dasar musik pop itu sendiri. Perlakuan ini tentu berbeda dengan yang dilakukan di dalam musik serius. Di dalam musik serius, penentuan grade bisa mengacu pada tingkat kesulitan karena memang tergolong di dalam musik seni: grade awal bisa berupa karya musik yang relatif mudah dari segi teknik. Grade selanjutnya lebih sulit. Grade yang berikutnya, lebih sulit lagi. Begitu seterusnya sampai tingkat yang sangat sulit, yang melibatkan segala aspek di dalam musikologi. Penentuan grade semacam ini mudah dipahami sebab pemaknaan istilah 'grade' mengindikasikan adanya tingkat atau jenjang. Penentuan atau penempatan karya musik pada jenjang tertentu bisa dipahami secara proporsional dan rasional dalam proses belajar mengajar.

Masalahnya bagaimana dengan musik pop? Seperti telah dijelaskan di atas, musik pop cenderung merupakan musik dagang dan hiburan untuk mencapai kesenangan pendengarnya. Lantas bagaimana filosofi semacam ini bisa diterapkan di dalam kurikulum di pendidikan tinggi? Karakter musik pop pun berorientasi pada kesederhaaan, baik dari segi melodi maupun syair, sesuai dengan karakter mass culture. Lalu bagaimana dengan penempatan grade-nya? Manakah yang lebih tinggi grade-nya, sebagai misal, antara lagu ciptaan Ahmad Dhani dengan ciptaan Kla Project, Ebiet G. Ade, atau The Massive? Pun, atas dasar apa penilaian itu? Ini baru sedikit pertanyaan yang niscaya akan muncul secara sistematis dan beruntun.

Paradigma, filosofi, dan logika musik pop dan musik klasik sangatlah berbeda. Perlakukan terhadap musik klasik belum tentu cocok jika dilakukan bagi musik pop. Yang baik di dalam musik klasik belum tentu baik juga di dalam musik pop. Ini dua dunia yang sungguh-sungguh berbeda, kalau tidak boleh dikatakan bertentangan; dunia kontemplatif dengan dunia hiburan; dunia serius dengan dunia main-main, padahal dunia pendidikan adalah dunia serius, dunia yang berhubungan dengan masa depan seseorang. Masa depan seseorang tidak bisa disikapi dengan mainmain. Jika dibuat ukuran secara kuantitatif 0 sampai 10, karya-karya Beethoven mungkin akan mendapat nilai 8, 9, bahkan 10 jika diperdengarkan di hadapan mahasiswa Jurusan Musik atau para pencinta musik serius. Tetapi, berapa nilai yang akan didapat Beethoven jika karya-karyanya diperdengarkan di hadapan sopir-sopir truk di warung Tegal (warteg) di seputaran Pantura? Lantas, bagaimana ini mata kuliah musik pop harus dibuat?

Jika mengacu pada hakikat musik pop, kurikulum yang diturunkan ke dalam mata kuliah-mata kuliah harus menyesuaikan diri dengan hakikat musik pop itu sendiri, di mana hiburan, kesenangan, dan keuntungan menjadi 'living form'-nya. Penentuan grade harus dilakukan dengan logika terbalik dari perspektif musik serius. Kurikulum musik pop yang baik harus mengacu pada konsep penciptaan, dan bukan performansi, mengingat musik ini sangat fleksibel sehingga, jika tidak, akan menyulitkan dalam menentukan kebenaran atau standar nilai estetisnya. Sebuah lagu yang 'tinggi' grade-nya justru merupakan lagu yang sederhana; semakin sederhana semakin baik; semakin mudah diingat syairnya semakin bagus, walaupun yang perlu juga digarisbawahi, keterampilan memainkan alat musik juga diperlukan sebagai kebutuhan standar dan memainkan peranan penting bagi keberhasilan penguasaan lagu. Di sini sistem interdisipliner menjadi tampak, karena sekurang-kurangnya mahasiswa juga dituntut untuk memahami kesusasteraan dan problemproblem humanisme. Progresi akord semakin sederhana, juga semakin estetis, dengan catatan keterampilan bermain 
musik berada pada standar tertentu, walaupun tidak setinggi tuntutan pada musik serius. Grade tertinggi di dalam sistem penciptaan musik pop terletak pada relasinya dengan televisi dan kemampuannya dalam ikut ambil bagian dalam kancah mass culture. Dengan demikian, urusan musik pop pada dasarnya bukan semata-mata urusan musikal, tetapi juga urusan sosial, dagang, dan spektakularitas.

\section{Penutup}

Oleh karena musik pop adalah musik industri, maka harus ditempatkan di dalam konteks industrialisasi. Musik pop bukan musik serius, maka harus secara proporsional ditempatkan sebagai musik hiburan, dan "suka atau tidak suka" kurikulum harus "menghamba" pada kenyataan tersebut. Musik pop agak berbeda dengan jazz yang seringkali terasa lebih berat dan eksklusif. Paradigma musik serius pada akhirnya tidak bisa diterapkan begitu saja di dalam musik pop. Jika dipaksakan kurikulum justru akan teralienasi dari hakikat, karakter, tujuan, dan eksistensi musik pop sendiri. Kurikulum musik pop dan musik jazz. keduanya disebut musik populer.

\section{Referensi}

Agger, Ben. 1992. Culture Studies as Critical Theory, London: E Palmer Press.

Collins, J. 1989. Uncommon Cultures: Popular Culture and Post-modernism, New York: Routledge.

Daniels, Patricia S., et al. 2003. Almanac of World Histoy. Washington D.C.: National Geographic.

Frits, S. 1983. Sound Effects: Youth, Leisure, and Politics of Rock. London: Constable.

Gans, Herbert J. 1974. Popular Culture and High Culture. New York: Basic Books, Inc., Publisher.

Ginsburg, Faye D. et al. 2002. The Consumers, Media Worlds: Anthropology on New
Terrain. London: University of Californis Pres.

Andy Hamilton, Andy. 2007. Aesthetics and Music. New York: Continuum.

Hariyadi, Mathias, 1995, "Mengapa Manusia Suka Bermain?" dalam Basis, No. 9, 1995.

Hardjana, Suka. 2002. "Eksistensi Musik Pop dalam Perkembangan Musik di Indonesia," dalam Kompas (surat kabar/ harian), 19 Mei 2002.

Hauser, Arnold. 1982. The Sociology of Art, trans. Kenneth J. Norhcott. London: University of Chicago Press.

Kotler, Philip. 1997. Manajemen Pemasar-an: Analisis, Perencanaan, Implementasi, dan Kontrol, terj. Hendra Teguh dan Ronny A. Rusli. New Jersey: Simon \& Schuster, (Asia) Pte., Ltd.

Labib, Muh. 2002. Potret Sinetron Indonesia, Jakarta: MU:3 Books.

MacDonald, Dwight. 1964. "A Theory of Mass culture." Bernard Rosenberg dan David Manning White, ed. Mass culture: The Popular Arts in America. London: Collirer MacMillan Publisher.

Mack, Dieter. 1995. Apresiasi Musik: Musik Populer. Yogyakarta: Yayasan Pustaka Nusatama.

Webster, Merriam. 2001. Merriam-Webster's Collegiate Dictionary, Tenth Edition. Springfield, Massachussets, USA: Merriam-Webster Incorporated.

Neuman, Matthius. 1978. "Towards an Integrated Theory of Imagination," dalam Jurnal of Philosophy Quarterly, Vol. Xviii, No.3.

Sasongko, Michael Hari, 2002 "Musik Pop yang Irrasional," dalam Kompas (Surat Kabar/ Harian), 19 Mei 2002.

Strinati, Dominic. 2007. Popular Culture, (terj. Abdul Mukhid, Popular Culture: An Introduction of Theories of Popular) Culture. Bandung.

Shuker, Roy. 2006. Understanding Popular Music. London: Routledge. 
Tschmuck, Peter. 1994. Creativity and Innovation in Music Industry. Netherlands: Springer.

William, Raymond. 2000. "The Tecnology and the Society," dalam John Thorton Caldwel, ed., Electronic Media and
Tecnoculture. New Jersey: Rutgers University Press.

Wolff, Janet. 1993. The Social Production of Art. New York: New York University Press. 